ENTREPRENEURSHIP AND SUSTAINABILITY ISSUES

ISSN 2345-0282 (online) http://jssidoi.org/jesi/

2019 Volume 6 Number 4 (June)

http://doi.org/10.9770/jesi.2019.6.4(9)

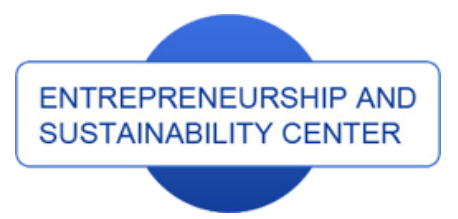

enterprise

europe

network

Publisher

Business Support on Your Doorstep

$\underline{\text { http://jssidoi.org/esc/home }}$

\title{
I Clarivate \\ SELECTED RISKS PERCEIVED BY SMES RELATED TO SUSTAINABLE ENTREPRENEURSHIP IN CASE OF ENGAGEMENT INTO CLUSTER COOPERATION*
}

\author{
Katarína Havierniková1, Marcel Kordoš² \\ 1,2 Faculty of Social and Economic Relations, Alexander Dubček University of Trenčín, Študentská 3, 91150 Trenčin, \\ Slovakia \\ E-mails. ${ }^{1}$ katarina.haviernikova@tnuni.sk $;{ }^{2}$ marcel.kordos@tnuni.sk
}

Received 15 November 2018; accepted 5 April 2019; published 30 June 2019

\begin{abstract}
Small and medium enterprises carry out their activities in a dynamic environment that is affected by various processes that also impact their sustainability. The future has the companies that are able to respond promptly to the challenges and are able to exploit opportunities sufficiently. One form of modern entrepreneurship that could help SMEs' sustainability in this environment is the cluster cooperation. This form of entrepreneurship brings many positive effects, but is also affected by various risks. The main aim of this study is to assess the perception of selected business risks that have an impact on SMEs' engagement into cluster cooperation. Using the questionnaire surveys of 1004 SMEs the perception was evaluated with emphasis on the differences between micro-small- and medium sized enterprises. From the data obtained, the tendencies are exposed through the evaluation of following risk categories such as: Market risks, Relation risks, Common resources risks, Operational risks, and Competency risks being assigned by a particular risk indicator afterwards. The final evaluation being made upon all respondents' answers analysis has confirmed that the competition risk turned out to be the most important risk indicator.
\end{abstract}

Keywords: cluster cooperation; small and medium enterprises; risk

\footnotetext{
* This research was supported by the project, which has received funding from the Ministry of Education of the Slovak Republic and of Slovak Academy of Sciences with title Risk management of SMEs in the context of clusters' involvement activities in the Slovak Republic, reg. Nr. VEGA [1/0918/16].
}
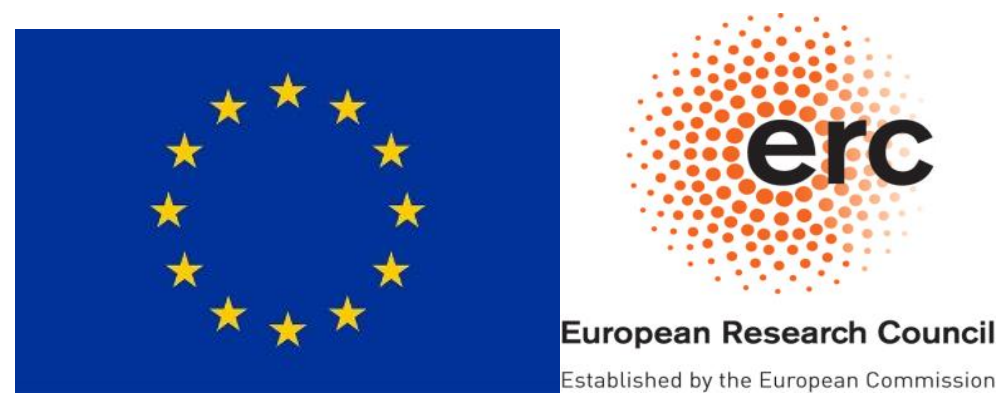


\section{ENTREPRENEURSHIP AND SUSTAINABILITY ISSUES}

ISSN 2345-0282 (online) http://jssidoi.org/jesi/

2019 Volume 6 Number 4 (June)

http://doi.org/10.9770/jesi.2019.6.4(9)

Reference to this paper should be made as follows: Havierniková, K.; Kordoš, M. 2019. Selected risks perceived by SMEs related to sustainable entrepreneurship in case of engagement into cluster cooperation, Entrepreneurship and Sustainability Issues 6(4): 1680-1693. http://doi.org/10.9770/jesi.2019.6.4(9)

JEL Classifications: G32, L14, C12

\section{Introduction}

The competitiveness of countries is determined by the ability of companies to succeed on global markets and to maintain their competitiveness. After industrialization reached its saturation in developed countries and percentage of value added generated by agricultural sector diminished, development economists ${ }^{6}$ discussion turned field of efficiency of economic sectors, estimated by total factor productivity (Tvaronavičienè, 2014). The sustainable competitiveness of companies is currently being achieved and maintained mainly through innovation. This activity needs to manage specific business steps, therefore Koval'ová \& Kulčár, (2017) recommended to use innovation management information systems. Innovation management system support the innovation implementation (Lewandowska \& Stopa, 2018). Innovative business activities are seen as a highly interactive process in which intensive contacts with customers, suppliers, and various collaborations have a major impact on companies' ability to offer competitive solutions (Drulák \& Druláková, 2014). These interactions make businesses tend to be geographically concentrated with many similarly sector-oriented businesses and institutions, and build mutually beneficial relationships, creating so-called clusters. The sector-oriented businesses with orientation on eco-innovations clusters are analysed by Stasiak-Betlejewska (2015). An example of a successful geographically localized cluster is a Silicon Valley in the USA (Obadi, Korcek, 2016).

Clustering firms can operate at a higher degree of efficiency and use the specialized assets of suppliers with shorter response times than when they operate in isolation. Spill-over effects and the interaction of companies with other stakeholders and customers create new ideas and increase pressure on innovation, with cluster environment reducing the cost of experimentation (Balaz \& Hamara 2016). In cooperation with research and development especially small and medium-sized enterprises can achieve a higher degree of innovation (Adamowicz \& Machla, 2016) and the difference between the growth of smaller firms and their larger counterparts can be even greater than without clustering (smaller firms grow mostly faster than larger ones (Fiala $\&$ Hedija, 2015)). The cluster environment also has a positive effect on the emergence of new and innovative companies that can connect to already existing relationships among individual cluster actors. Clusters, as groupings of actors in individual sectors, are considered by Cohesion Policy to be entities that can play a key role in regional development and sustainable competitiveness within the cooperation of stakeholders. In market economy, the competitiveness of regions depends on the competitiveness and economic growth of its actors in national economy.

The cluster concept represents a new direction in economic thinking. Brakman (2006) considers clustering to be a higher form of networking, bringing together the interests of the state, public and private spheres. For market economy development is according to Mura \& Rózsa (2013) very important to create business networks, clusters and innovation. Already existing horizontal level networks have the possibility of linking to the vertical level in order to achieve a higher added value of their activity with a demonstrably positive impact on the development of the regions (Fojtikova, 2016). The key role of clusters in the initial phase is to analyze the development potential of the regions by linking their activities to effectively support economic activities as well as the economic growth of the territory through creating the horizontal and vertical links (Mura et al., 2017). An important aspect in cluster formation and goal definition is to build a cluster strategy involving actors from all sectors as their activities complement and influence each other. The members of developed clusters are mainly the representatives of SMEs. According Fabuš (2015), the key factor in economic development and growth of Slovakia are foreign 


\section{ENTREPRENEURSHIP AND SUSTAINABILITY ISSUES}

ISSN 2345-0282 (online) http://jssidoi.org/jesi/

2019 Volume 6 Number 4 (June)

http://doi.org/10.9770/jesi.2019.6.4(9)

direct investments, which also affects the development of SMEs. Also, the incentives operating in the country through two ways of promoting investment environment, namely: EU structural funds which are translated directly to support small and medium enterprises, and development of infrastructure and manpower as well as other forms of state aid for the strategic investors at the regional level (Fabuš, 2014). Due to this fact, the clusters could contribute to the development of sustainable entrepreneurship of SMEs also in Slovak regions.

Only companies being able to respond promptly to challenges occurring under the current turbulent processes within the international business environment and exploit opportunities emerging from mutual collaboration based on innovation activities sufficiently can gain the benefits from the dominant position on market. One form of modern entrepreneurship that could enhance SMEs' sustainability in this environment is the cluster cooperation. That is why the research task of this study is focused on the perception assessment of selected business risks that have an impact on SMEs' engagement into cluster cooperation. This paper will discuss the issue how and in what way the form of entrepreneurship brings many positive effects, while being also affected by various risks. To put it in other words, this subject deals with the level of understanding regarding the five main sections of business risks having been considered by respondents in terms of involvement into cluster cooperation when highlighting sustainable entrepreneurship.

\section{Clustering issues within entrepreneurship risk management and sustainability - Theoretical background}

Globalization has always been a source of competitive advantage. International businesses have thus gained an advantage over domestic businesses. The new phase of globalization, on the contrary, increases the significance of the domestic base (Malec \& Abrham, 2016). Previously, the size of the company was important, but today the size of the particular grouping within a cluster collaboration is getting more and more crucial (Burda, Abrham, Horvathova, 2017). That means that company can be even smaller, but it is important that it has enough good suppliers and supportive businesses and institutions around (Mura, Marchevska, Dubravska, 2018). This development of globalization puts emphasis on specialization, namely to make the specific things best done in specific locations. A new pattern of sustainable competition has emerged, which is based on innovation, modernization and specialization (Miklosik, Kuchta, Zak, 2018). Each locality can achieve a unique specialty when cooperating with mutual contractors. Competition rather means competition for share of opportunities, market share; that is why companies get together into clusters (Fojtikova \& Stanickova, 2017; Hilkevics, Semakina, 2019).

Cluster was defined and implemented in 1990 by Michael E. Porter, but the issue of clusters is much older. Alfred Marshall, who formulated the theory of industrial districts, laid down the foundations of this issue in the $19^{\text {th }}$ century. Michael E. Porter defined cluster as "a geographically close group of interconnected companies and related institutions in a particular field, linked by common features and complementarities" (Hamilton \& Wepster, 2009) Thus, cluster can be understood as a geographically close group of affiliated companies and institutions in a certain area that cooperate and also compete with each other. Within the cluster, several types of entities can be grouped, such as research and education institutions, business enterprises, businesses providing different services to other enterprises within cluster, machine and production technology suppliers, suppliers of various parts and semi-finished products to the final product manufacturer (Cihelkova, 2016). Cluster brings together supply-chain relationships or joint technologies, possibly joint customers and distribution channels, or according to Horecký (2018) and Mészáros (2018) common labor markets and human capital (Lorincová, 2018; Žul’ová, Švec, Madleňák, 2018). Human resources are the one of important premises for realization of network creating. Due to the facts stated above, we can consider the clusters as the important tool for sustainable development of SMEs.

Significant term within the issue of clusters is the so-called Porter's diamond mode highlighting the competitive advantages of clusters, which do not depend on individual companies, but from the continuity of the entire cluster, the diamond. The diamond of competitive advantages consists of following major factors (Vojtovic, 2016): 


\section{ENTREPRENEURSHIP AND SUSTAINABILITY ISSUES}

ISSN 2345-0282 (online) http://jssidoi.org/jesi/

2019 Volume 6 Number 4 (June)

http://doi.org/10.9770/jesi.2019.6.4(9)

conditions of entry factors, conditions of demand, related and supportive industries, strategy and rivalry of companies, the government.

Links among cluster actors can be conducted through three channels: material, personnel and information delivery/customer relations. There may also be a different hierarchy of links among individual cluster actors, thus creating different relationships, either on the basis of equivalence, or a major enterprise represents a central point linked to other enterprises by mutual ties (Varadzin, 2016). In addition, there may also be a multi-level hierarchy of suppliers when there is occurring a specializes of individual businesses on particular value chain levels, or socalled technological, non-hierarchical structure in which business relations focus primarily on personnel and information transfer (Taušer \& Čajka, 2014). Cluster is an excellent tool how to achieve local, regional and national sustainable development, of which goal is to find common interest and matching being determined, as a high-performance cluster, by a collaboration at four basic levels, being shown below within the Figure 1.

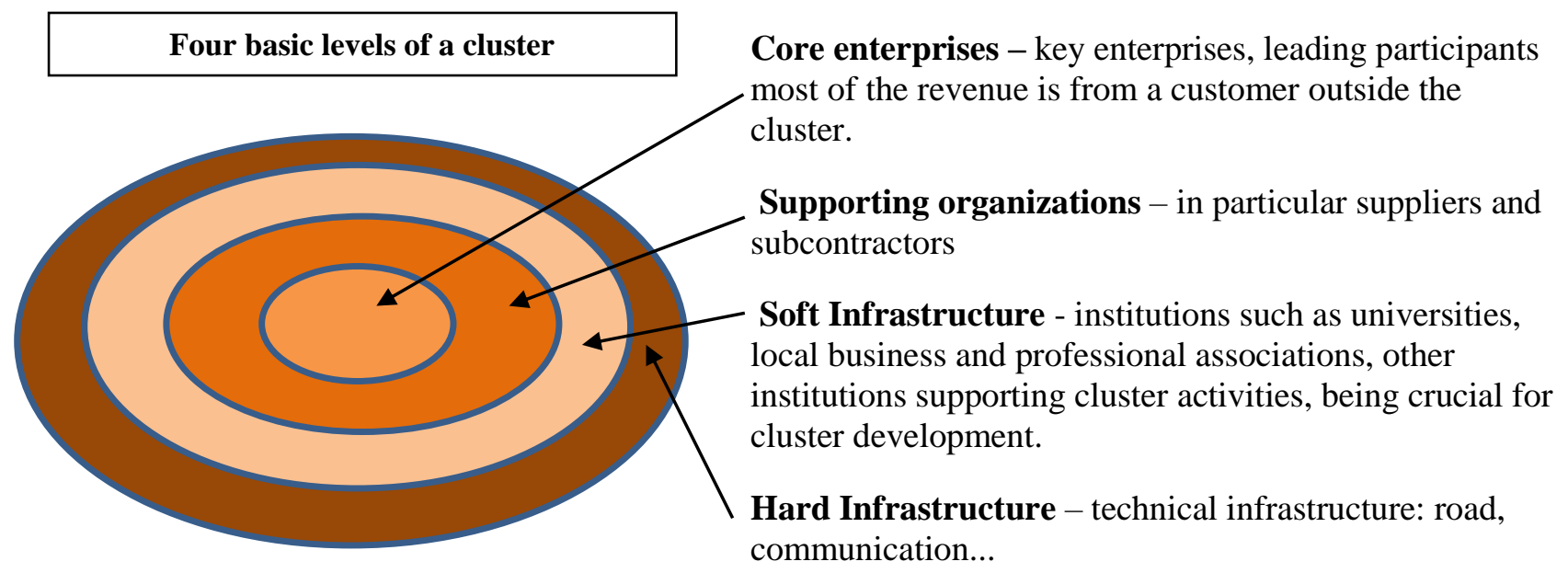

Fig. 1. Four basic levels of a cluster

Source: own processing by Lipkova \& Braga (2016).

Entry factor conditions are human resources, raw materials, knowledge, capital and infrastructure. Terms of demand create prerequisites for competition. Strategy and rivalry of companies are characterized by competition among companies (Sejkora, 2014). Related and supportive industries represent the ability of local companies to deliver cost-effective inputs and to participate in innovative business processes (Lemańska-Majdzik, Okręglicka 2015). The government, whether regional or national, affects individual parts of the diamond in a suitable competitive environment and encourages competitiveness by demand stimulation. Government should respond to the needs of clusters, such as promotion of innovation, research, development and education, or appropriate infrastructure creation (De Castro, Hnat, 2017). Balaz (2015) argues that clustering has a positive impact on innovation and competitiveness, capacity building and information, growth and sustainable business dynamics.

In each human activity, storylines and processes, and of course business activities, all activities are not carried out in the way the carrier plans for them, but they are being executed under conditions of uncertainty. The stage of uncertainty in specific conditions presents a risk. Risk is an important element that affects the safety of systems. It represents such a fact, which may unexpectedly bring up benefits but also cause a loss (Abrhám \& Lžičař, 2018). The risk is associated especially within the distinction between planned and already achieved goals, as well as the 


\section{ENTREPRENEURSHIP AND SUSTAINABILITY ISSUES}

ISSN 2345-0282 (online) http://jssidoi.org/jesi/

2019 Volume 6 Number 4 (June)

http://doi.org/10.9770/jesi.2019.6.4(9)

possibility of invested funds loss. The investor gains significant decision-making power in the company where he invests. (Fabus \& Csabay, 2018). Risks can be reduced by implementing preventive measures and risk-awareness (Machkova \& Sato, 2017). The risk can be expressed in various ways (standard deviation, variation coefficient, frequency e.g. distribution function, relative difference between the actual and expected loss, etc.). The entrepreneur as a manager can have attitude to a risk: averse, neutral or may have a tendency to risk (Dano \& Lesakova, 2018). In terms of entrepreneurial activity, the following types of risk can be determined: basic types of risk: business risk, the net risk; based on the substantive content: technical, manufacturing, economic, market, political risk; risk by binding to the businesses: systematic risks (e.g. changes caused by scientific and technological progress, increasing income tax rates, reduced purchasing power, electricity prices rising, etc.), nonsystemic risks (e.g. non-conformity with technical progress, delays in product innovation, production facilities failure, etc.); risk in terms of its suggestibility: modifiable, uncontrollable risks and other risks. The business risk can be understood as a deviation of the actual economic result of entrepreneurship from planned results. Business risk can be characterized as the likelihood of taking a negative direction from reaching identified goals (Fabuš, 2017). By this term all activities or attributes will be understood, whose performance can cause negative consequences in an enterprise. All activities of an enterprise are derived from a strategy and therefore it is logical that a mistake in strategy brings impacts on all subsystems of an enterprise (Hanulakova \& Dano, 2018; Zak, 2012). The uniqueness of industrial cooperation lies in the fact that it reduces the risk of failure in business, creates additional jobs, gives a positive experience and knowledge, and, therefore, it is a factor in the development of entrepreneurship (Fomina et al., 2018).

In economic practice of business entities, the activity the essence of which is the effective management of potential opportunities and possible undesirable consequences is called "the Risk management" (Tauser, Cajka, 2014). The basic assumption is that it must be an integral part of any management practice regardless of the management level. The risk management process includes risk identification, risk analysis and risk management planning (Sejkora \& Sankot, 2017). Risk identification is determining which risks may affect the cluster activities. Possible problems in activities undertaken by a cluster are being identified. A risk most often is considered as the uncertainty of environmental factors impact on the functioning of organization and meeting its objectives. The risk can be seen from two perspectives: the existence of an external threat (external risks) and risk associated with its own activities (internal risks). Regarding the risk definition in clusters, it is necessary to have a look at this issue from two perspectives. The first aspect is the specificity of risk definition in particular bodies, and the second one is the specificity of cluster by itself (Zemanova \& Drulakova, 2016).

In order to achieve the sustainability of business environment, especially in the area of small and medium-sized enterprises, a balanced and market-conforming strengthening and streamlining of the state's role is crucial within the implementation of allocation, distribution, stimulation and stabilization function of public finances by means of systemic formation and effective use of state budget and fiscal policy instruments (Zadrazilova, 2016; Okanazu, 2018). Evaluating the quality of the business environment appears to be another way to assess the level of the individual components of business environment. It is important to select appropriate indicators and select appropriate resources (Fabus, 2018). The aim is to create gradually the prerequisites for a knowledge-based growth of a society in consolidating macroeconomic stability and business development, with particular reference to job creation. The government's priority is such financial support for healthcare and social services that enhances their efficiency and quality. In upcoming years, policy areas will be a political priority for governments, with special regard to education, research and transport infrastructure (Vojtovic, Navickas, Gruzauskas, 2016). The microeconomic level of business environment sustainability is geared to changes within the production process and provided services. Businesses are trying to implement innovative processes and implement new technologies to achieve the suistanable business. Because of these changes, they market new products and services. They also follow new production links with foreign manufacturers and adjust their production program (Taušer, Arltová, Žamberský, 2015). Sale is another business tool. Its goal is to maintain original markets and to find new outlets. On the other hand, businesses set new sales conditions, adjusting prices and tariffs, and are 


\section{ENTREPRENEURSHIP AND SUSTAINABILITY ISSUES}

ISSN 2345-0282 (online) http://jssidoi.org/jesi/

2019 Volume 6 Number 4 (June)

http://doi.org/10.9770/jesi.2019.6.4(9)

trying to shorten the delivery time for ordered goods and services (Lipkova, Hovorkova, 2018). Those are the ways to meet growing and sustainable business environment suitable for cluster collaboration development.

\section{Problem Formulation and Methodology}

The main research problem of this study was focused on the level of perception of the five main categories of business risks that respondents consider in case of engagement into cluster cooperation towards suistanable entrepreneurship. A subjective perception of risks was assigned by respondents on Likert scale from 0 insignificant type of risk to 5 - the most important. Evaluated risk categories in this study are presented through the indicators that correspond with given category and with the connection into cluster cooperation. To state the risk categories and indicators we followed works from this research field of several authors (see table 1). The risk categories were selected by following Camarinha-Matos et al. (2015).

Table 1 Risk factors in cluster cooperation

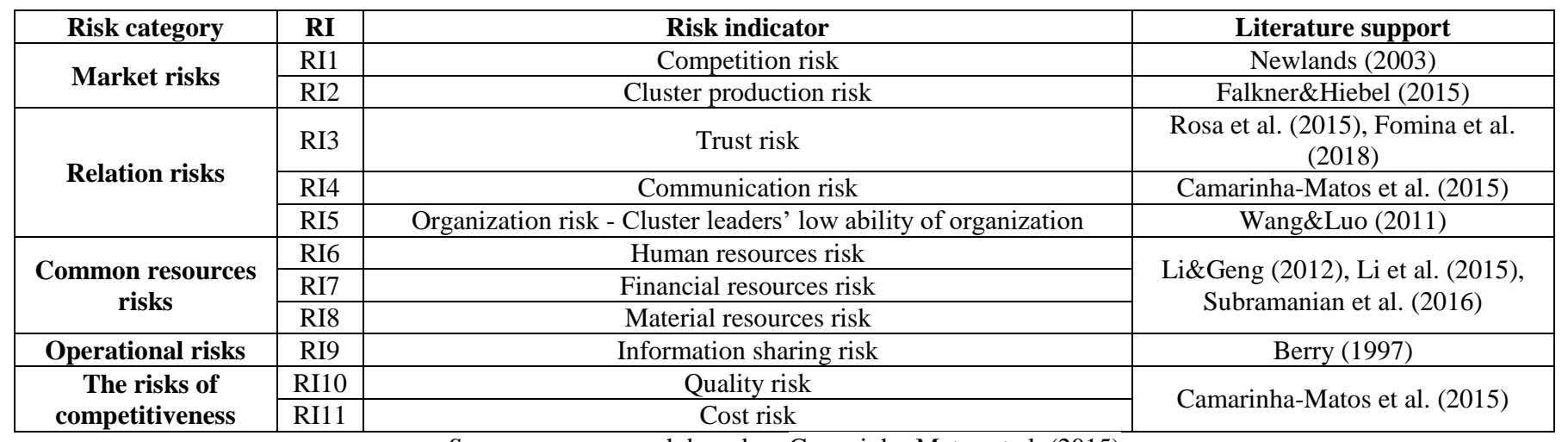

Source: own research based on Camarinha-Matos et al. (2015)

In the research we focused on the findings, whether among the responses of SMEs, categorized by their sized category, the statistical significant differences are presented. To meet the main aim the quantitative method "analysis of variance" was used by following Hudáková \& Masár (2018). The analysis of variance can be determined by the parametric or non-parametric tests. For using the calculation of the parametric tests two basic conditions had to be met: the resulting p-value of the intensity of the risks of the homoscedasticity test (identity of variances) and the normality test. If these conditions are not met, a nonparametric test is required.

We have used the Shapiro-Wilk test to verify normality, with a null hypothesis H0: random selection $X_{1}, X_{2}, . ., X_{n}$ originates from a basic set with normal distribution against the alternative hypothesis H1: the selection comes from a basic file with another layout. Calculated test statistic we compared to the corresponding p-value. In the case that the $\mathrm{p}$-value is greater than the chosen significance level $\alpha=0.05$, the hypothesis H0 is not rejected. Otherwise, we accepted alternative hypothesis $\mathrm{H} 1$ at the level of significance $\alpha$. The calculation was carried out in the program STATISTICA. To test the homogeneity of variance we have used the Levene's test. This test is used if $k$ samples have equal variances. By Levene's test we tested null hypothesis H0: We assume that variables in populations do not differ $\mathrm{H} 0: \sigma_{1}{ }^{2}=\sigma_{2}{ }^{2}=\ldots=\sigma_{\mathrm{n}}{ }^{2}$ against alternative hypothesis $\mathrm{H} 1: \sigma_{1}{ }^{2} \neq \sigma_{2}{ }^{2} \neq \ldots \ldots \neq \sigma_{\mathrm{n}}{ }^{2}$ that claims, that at least one pair of variances is different. The significance level is $\alpha=0.05$. If the result of $p$-value is higher than $\alpha$, the $\mathrm{H} 0$ is accepted. In otherwise the $\mathrm{H} 1$ is valid.

Due to the results of normality testing by using Shapiro-Wilks test and its correction Lilliefors and p-values for each item, we used the non-parametric test - Kruskal Wallis (one-way analysis of variance by ranks) that is testing equality of population medians among groups. This test was used to compare mean and variability of more 
than two groups. In this study the non-parametric Kruskal Wallis Test was used to find the differences between size categories of SMEs with respect to various level of risk perception.

Statistical hypothesis are formulated as follow:

H0: ranks do not differ among groups H1: ranks differ among groups

In the case that the $\mathrm{p}$-value is greater than the chosen significance level $\alpha=0.05$, the hypothesis $\mathrm{H} 0$ is not rejected. Otherwise, we accepted alternative hypothesis $\mathrm{H} 1$ at the level of significance $\alpha$. The calculation was carried out in the STATISTICA program.

\section{Results and discussion}

The research was conducted in eight Slovak regions through questionnaire surveys in years 2016-2017. A total of 1004 owners or managers (competent persons) of small and medium enterprises (SMEs) were involved in our research. The participation on survey for SMEs was limited by their experience or knowledge of cluster cooperation. Next tables show the results of statistical analysis to each question of the survey. The structure of respondents presents table 2 .

Table 2. The structure of respondents

\begin{tabular}{|c|c|c|c|c|}
\hline \multirow{2}{*}{ Region } & \multicolumn{3}{|c|}{ Size category of respondets } & \multirow{2}{*}{ Total } \\
\hline & Micro (0-9 employees) & Small (10-49 employees) & Medium (50-249 employees) & \\
\hline Bratislava & $2,79 \%$ & $3,78 \%$ & $2,49 \%$ & $9,06 \%$ \\
\hline Trnava & $2,79 \%$ & $3,78 \%$ & $2,49 \%$ & $9,06 \%$ \\
\hline Trenčín & $18,73 \%$ & $13,65 \%$ & $6,27 \%$ & $38,65 \%$ \\
\hline Nitra & $1,89 \%$ & $1,59 \%$ & $1,29 \%$ & $4,78 \%$ \\
\hline Žilina & $10,96 \%$ & $8,47 \%$ & $3,88 \%$ & $23,31 \%$ \\
\hline Banská Bystrica & $1,69 \%$ & $1,20 \%$ & $0,80 \%$ & $3,69 \%$ \\
\hline Košice & $4,18 \%$ & $3,29 \%$ & $1,49 \%$ & $8,96 \%$ \\
\hline Prešov & $1,20 \%$ & $1,59 \%$ & $0,40 \%$ & $3,19 \%$ \\
\hline Total & $44,62 \%$ & $37,15 \%$ & $18,23 \%$ & \\
\hline
\end{tabular}

There is the necessary information for analysis of variance in each following tables. These are the basic statistical characteristics: the average of respondents' evaluation, the range of respondents' evaluation, standard deviation. There are also the results of used tests for verification of normality and the homogeneity of variance. The results of Levene's test and Shapiro-Wilk test showed the necessity of using nonparametric test - Kruskal Wallis Test (KW test).

The first evaluated category was Market risk. Within this category, two risk indicators were evaluated RI1 Competition risk and RI2 Cluster production risk. These risks are related to the sale of sustainable products or the providing of sustainable services. As the most risky indicator in this category was marked by respondents the RI1 mainly by micro $(3.36 \pm 1.40)$ and small $(3.36 \pm 1.28)$ enterprises. The risk indicator RI2 was important mainly for small enterprises (2.61 \pm 1.41$)$. Based on the results of KW test for RI1 (the p value is higher than 0.05) we can therefore claim that there are not the differences among the medians of respondents' evaluation of this risk indicator, with a confidence level of $95.0 \%$. On the opposite side, for indicator RI2, the calculated p-value is lower than 0.05. We can therefore claim that the differences among the medians of respondents' evaluation of this risk indicator are statistically significant among the involved groups of respondents (with a confidence level of 95.0\%). 
ENTREPRENEURSHIP AND SUSTAINABILITY ISSUES

ISSN 2345-0282 (online) http://jssidoi.org/jesi/

2019 Volume 6 Number 4 (June)

http://doi.org/10.9770/jesi.2019.6.4(9)

Table 3. The evaluation of Market risks

\begin{tabular}{|c|c|c|c|c|c|c|c|c|c|}
\hline $\begin{array}{c}\text { Market } \\
\text { risks }\end{array}$ & Sized category & Mean & $\mathbf{N}$ & SD & Variance & $\begin{array}{c}\text { Levene's } \\
\text { test }\end{array}$ & $\begin{array}{l}\text { Shapiro- } \\
\text { Wilk test }\end{array}$ & Lilliefors & $\begin{array}{c}\text { Kruskal Wallis } \\
\text { test }\end{array}$ \\
\hline \multirow[b]{2}{*}{ RI1 } & Micro (0-9 employees) & 3.36 & 448 & 1.40 & 1.96 & \multirow{2}{*}{$\begin{array}{c}F=3.927 \\
p=0.02\end{array}$} & \multirow{2}{*}{$\begin{array}{c}\mathrm{SW}=0.889 \\
\mathrm{p}<0.00\end{array}$} & \multirow[b]{2}{*}{$\mathrm{p}<0.01$} & \multirow{2}{*}{$\begin{array}{c}H(2, N=1004) \\
=0.360 \mathrm{p}=0.835\end{array}$} \\
\hline & Small (10-49 employees) & 3.36 & 373 & 1.28 & 1.64 & & & & \\
\hline \multirow[b]{2}{*}{ RI2 } & Micro (0-9 employees) & 2.36 & 448 & 1.41 & 1.98 & \multirow{2}{*}{$\begin{array}{c}\mathrm{F}=0.006 \\
\mathrm{p}=0.99\end{array}$} & \multirow{2}{*}{$\begin{array}{c}\mathrm{SW}=0.931 \\
\mathrm{p}<0.00\end{array}$} & \multirow[b]{2}{*}{$\mathrm{p}<0.01$} & \multirow{2}{*}{$\begin{array}{c}H(2, N=1004) \\
=6.969 p=0.031\end{array}$} \\
\hline & Small (10-49 employees) & 2.61 & 373 & 1.41 & 1.97 & & & & \\
\hline
\end{tabular}

Source: own research and processing in program STATISTICA

The second category - Relation risks, consists of three risk indicators: RI3 Trust risk, RI4 Communication risk and RI5 Organization risk - Cluster leaders' low ability of organization (table 3). Good relationships among cluster' stakeholders and with customers are the basis for as well as stakeholders, as well as whole cluster towards their long-term sustainability. If we compared the respondents' evaluation of these risk indicators, we observed as the most important indicator RI4. In the respondents' evaluation, according sized category, this risk indicator was the most important for small enterprises (3.11 \pm 1.49$)$. The results of p-value of KW test for RI3 and RI4 are higher than 0.05 . We can therefore claim, with a confidence level of $95.0 \%$, that the differences among the medians of respondents' evaluation of these risk indicators are not statistically significant among the involved sized category of enterprises. It means, that size category of respondents doesn't affect their evaluation of stated indicators. The p-value of KW test, calculated in case of RI5 showed lower level than the reference p - value is.. Therefore the differences among the medians of respondents' evaluation of this indicator are statistically significant. The respondents' evaluation of this indicator depends on the sized category of enterprise (table 4).

Table 4. The evaluation of Relation risks

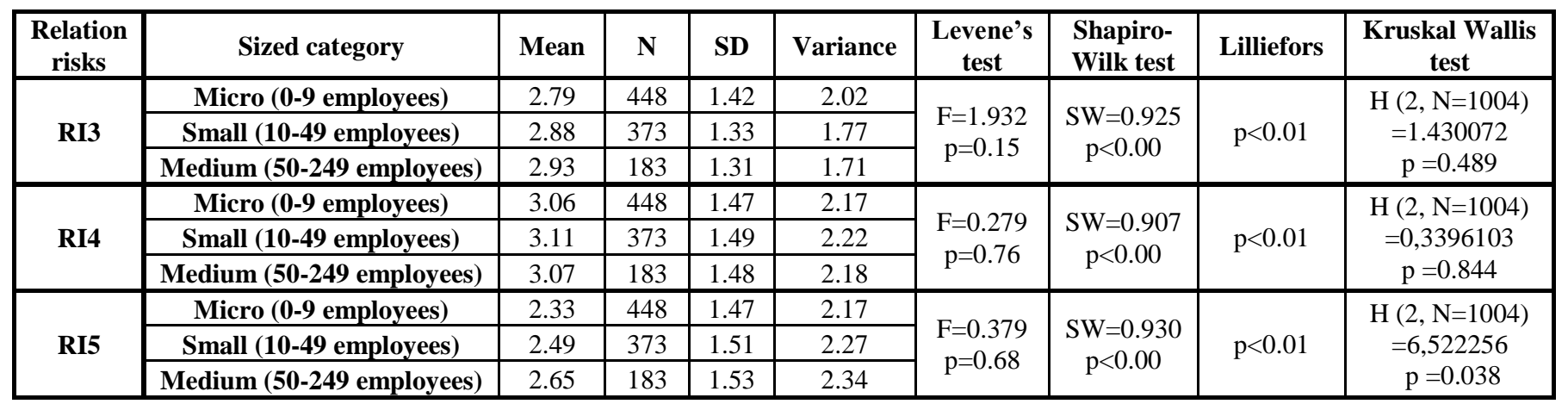

Source: own research and processing in program STATISTICA

Table 5 shows the results of respondents' evaluation of other three indicators from risk category of Common resources: RI6 Human resources risk, RI7 Financial resources risk and RI8 Material resources risk. These three categories of resources are the key resources of each SMEs' sustainable entrepreneurship. The using of these resources towards sustainable entrepreneurship is linked with a certain level of risk. The highest average value of respondents' answers $(3.16 \pm 1.43)$ was recorded for RI6 by category of small entrepreneurs. The lowest average value we can see in case of RI8 $(2.38 \pm 1.56)$ evaluate by group of small enterprises. The results of p-values calculated by KW test are higher in all three cases than value of 0.05 . We admit the 0.95 probability of reliability that among the individual responses of the respondents in the surveyed SMEs, the difference in mean values is not statistically significant. 
ENTREPRENEURSHIP AND SUSTAINABILITY ISSUES

ISSN 2345-0282 (online) http://jssidoi.org/jesi/

2019 Volume 6 Number 4 (June)

http://doi.org/10.9770/jesi.2019.6.4(9)

Table 5. The evaluation of Common resources risks

\begin{tabular}{|c|c|c|c|c|c|c|c|c|c|}
\hline $\begin{array}{l}\text { Common } \\
\text { resources } \\
\text { risks }\end{array}$ & Sized category & Mean & $\mathbf{N}$ & SD & Variance & $\begin{array}{c}\text { Levene's } \\
\text { test }\end{array}$ & $\begin{array}{l}\text { Shapiro- } \\
\text { Wilk test }\end{array}$ & Lilliefors & $\begin{array}{c}\text { Kruskal } \\
\text { Wallis test }\end{array}$ \\
\hline \multirow{2}{*}{ RI6 } & Micro (0-9 employees) & 3.00 & 448 & 1.51 & 2.28 & \multirow{2}{*}{$\begin{array}{c}\mathrm{F}=0.040 \\
\mathrm{p}=0.96\end{array}$} & \multirow{2}{*}{$\begin{array}{c}\mathrm{SW}=0.909 \\
\mathrm{p}<0.00\end{array}$} & \multirow{2}{*}{$\mathrm{p}<0.01$} & \multirow{2}{*}{$\begin{array}{c}\mathrm{H}(2, \mathrm{~N}=1004) \\
=2.510538 \\
\mathrm{p}=0.285\end{array}$} \\
\hline & Medium (50-249 employees) & 3.01 & 183 & 1.51 & 2.29 & & & & \\
\hline \multirow[b]{2}{*}{ RI7 } & Micro (0-9 employees) & 2.92 & 448 & 1.51 & 2.27 & \multirow{2}{*}{$\begin{array}{c}\mathrm{F}=2.301 \\
\mathrm{P}=0.10\end{array}$} & \multirow{2}{*}{$\begin{array}{c}\mathrm{SW}=0.910 \\
\mathrm{p}<0.00\end{array}$} & \multirow[b]{2}{*}{$\mathrm{p}<0.01$} & \multirow{2}{*}{$\begin{array}{c}\mathrm{H}(2, \mathrm{~N}=1004) \\
=2.612434 \\
\mathrm{p}=0.271\end{array}$} \\
\hline & Small (10-49 employees) & 3.09 & 373 & 1.40 & 1.97 & & & & \\
\hline \multirow{3}{*}{ RI8 } & Micro (0-9 employees) & 2.40 & 448 & 1.61 & 2.61 & \multirow{3}{*}{$\begin{array}{c}\mathrm{F}=0.553 \\
\mathrm{p}=0.58\end{array}$} & \multirow{3}{*}{$\begin{array}{c}\mathrm{SW}=0.919 \\
\mathrm{p}<0.00\end{array}$} & \multirow{3}{*}{$\mathrm{p}<0.01$} & \multirow{3}{*}{$\begin{array}{c}\mathrm{H}(2, \mathrm{~N}=1004) \\
=0.0745514 \\
\mathrm{p}=0.963\end{array}$} \\
\hline & Small (10-49 employees) & 2.38 & 373 & 1.56 & 2.44 & & & & \\
\hline & Medium (50-249 employees) & 2.42 & 183 & 1.59 & 2.53 & & & & \\
\hline
\end{tabular}

Source: own research and processing in program STATISTICA

The comprehensive development of cluster stakeholders requires innovative cooperation based on the information sharing. The increasing of the dynamics of the meaning of creation and application of effective information systems will contribute to better customer satisfaction and response to market opportunity. Table 6 consists of evaluation of risk indicator RI9 Information sharing risk that was included in the category of Operational risks. This indicator considers respondents from category of small enterprises $(2.77 \pm 1.41)$ as the most important. The level of p-value of KW test is lower than 0.05 , it means that ranks of respondents' differ among group according size category.

Table 6. The evaluation of Operational risks

\begin{tabular}{|c|c|c|c|c|c|c|c|c|c|}
\hline $\begin{array}{c}\text { Operational } \\
\text { risks }\end{array}$ & Sized category & Mean & $\mathbf{N}$ & SD & Variance & $\begin{array}{c}\text { Levene's } \\
\text { test }\end{array}$ & $\begin{array}{c}\text { Shapiro- } \\
\text { Wilks test }\end{array}$ & Lilliefors & $\begin{array}{c}\text { Kruskal Wallis } \\
\text { test }\end{array}$ \\
\hline \multirow{2}{*}{ RI9 } & Micro (0-9 employees) & 2.49 & 448 & 1.42 & 2.02 & \multirow{2}{*}{$\begin{array}{c}\mathrm{F}=0.482 \\
\mathrm{p}=0.62\end{array}$} & \multirow{2}{*}{$\begin{array}{c}\mathrm{SW}=0.929 \\
\mathrm{p}<0.00\end{array}$} & \multirow{2}{*}{$\mathrm{p}<0.01$} & \multirow{2}{*}{$\begin{array}{c}\mathrm{H}(2, \mathrm{~N}=1004) \\
=9.947492 \\
\mathrm{p}=0.007\end{array}$} \\
\hline & Small (10-49 employees) & 2.77 & 373 & 1.41 & 1.98 & & & & \\
\hline
\end{tabular}

Source: own research and processing in program STATISTICA

The category of Competency risks consists of risk indicators R10 Quality risk and R11 Cost risk. The quality and cost are considered as the measures for the strategic objectives of enterprises. The RI10 was perceived as the most important in case of small enterprises $(3.35 \pm 1.41)$ and R11 by medium sized enterprises (3.02 \pm 1.48$)$. In case of RI10 the calculated p - value is higher than 0.05 and in the case of RI11 is lower. In case of RI10 the null hypothesis (H0: ranks do not differ among groups) was confirmed and in case of RI11 the alternative hypothesis (H1: ranks differ among groups of respondents) was accepted (table 7).

Table 7. The evaluation of Competency risks

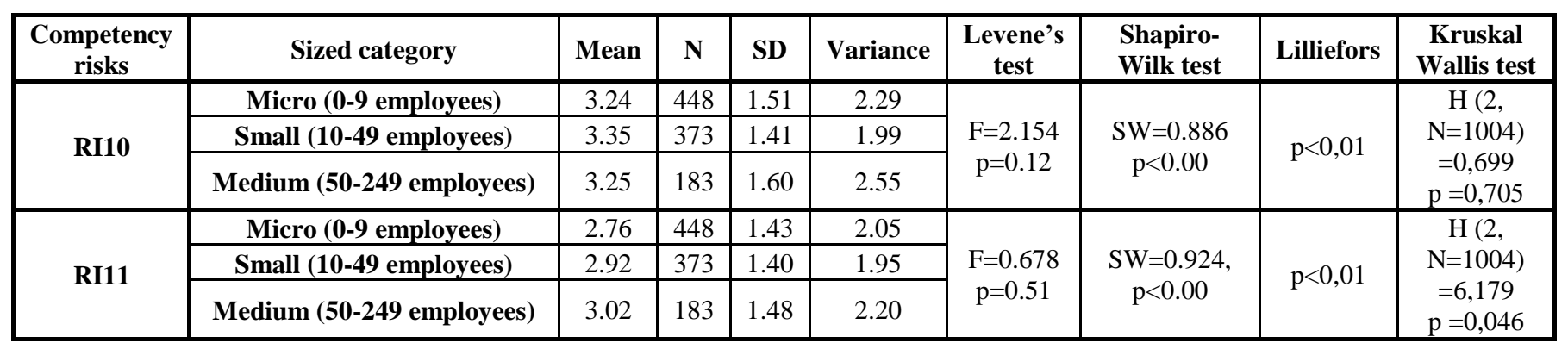

Source: own research and processing in program STATISTICA 


\section{ENTREPRENEURSHIP AND SUSTAINABILITY ISSUES}

ISSN 2345-0282 (online) http://jssidoi.org/jesi/

2019 Volume 6 Number 4 (June)

http://doi.org/10.9770/jesi.2019.6.4(9)

\section{Conclusions}

The cluster cooperation towards sustainable entrepreneurship brings various risks. This is confirmed also by scientists who deal with this topic. Rosas et al. (2015) stated that there is the risk of dependence on the partner behavior for cooperation, Abhari et al. (2017) notice the risk of own reputation losing, Falkner \& Hiebel (2015) argue that there is the risk of dependence on cluster production. Collective action may assist the prospect of success of individual firms but there is the risk it blunts initiative and inhibits competition (Newlands, 2003). Cluster cooperation allows the distribution of risks among cluster's stakeholders. The key aspect of this business is the relationship between competition and cooperation between firms and other actors within clusters (Newlands, 2003). The sustainable competitiveness of clusters is the ability to compete, growth, and to make profit from their products, services or other clusters' outputs, if the condition of quality, cost and appropriate use of resource are met. (see also Li\&Geng, 2012, Li et al., 2015, Subramanian et al., 2016, Camarinha-Matos et al., 2015)

The results of our research showed the SMEs' perception of selected risk categories evaluated by risk indicators in the context of sustainable entrepreneurship. Table 8 shows the evaluation of risk indicators sorted by their importance based on the average value of respondents' answers. As we can see, all respondents (regardless of the size categorization of enterprise) stated that the most important risk indicators are RI1 Competition risk $(3,38 \pm 1.32)$ and RI10 Quality risk (3.28 \pm 1.49$)$. The least important is RI8 Material resources risk (2.40 \pm 1.59$)$.

Table 8. The ranking of risk indicators

\begin{tabular}{|c|c|c|c|}
\hline RI & Risk indicator & Mean & Standard deviation \\
\hline RI1 & Competition risk & 3.38 & 1.32 \\
\hline RI10 & Quality risk & 3.28 & 1.49 \\
\hline RI4 & Communication risk & 3.08 & 1.48 \\
\hline RI6 & Human resources risk & 3.06 & 1.48 \\
\hline RI7 & Financial resources risk & 3.00 & 1.47 \\
\hline RI11 & Cost risk & 2.86 & 1.43 \\
\hline RI3 & Trust risk & 2.85 & 1.37 \\
\hline RI9 & Information sharing risk & 2.60 & 1.42 \\
\hline RI2 & Cluster production risk & 2.48 & 1.41 \\
\hline RI5 & Organization risk - Cluster leaders' low ability of organization & 2.45 & 1.50 \\
\hline RI8 & Material resources risk & 2.40 & 1.59 \\
\hline
\end{tabular}

Source: own research

Based on the results of realization of analysis of variance, when we used the non-parametric Kruskal-Wallis test, we can conclude, that significant statistical differences among respondents' answers we can observe in case of following risks indicators: RI2 Cluster production risk, RI5 Organization risk - Cluster leaders' low ability of organization, RI9 Information sharing risk, RI11 Cost risk. It means that assessment of this indicators depends on size category of respondents.

The application of risk management and specific risk management practices within clusters represent a spectrum of specific management activities application that influence the decision making, strategy, and operational activities of the cluster as a whole. The emphasis on a coordinated approach to risk is an effective way to increase the certainty that stakeholders have the desired effect on sustainable enterprise development. A good orientation in possible threats resulting from engagement in a cluster should enable the involved subject to help reduce these threats and subsequently suppress negative fallouts of a different environment in practice. 


\section{ENTREPRENEURSHIP AND SUSTAINABILITY ISSUES}

ISSN 2345-0282 (online) http://jssidoi.org/jesi/

2019 Volume 6 Number 4 (June)

http://doi.org/10.9770/jesi.2019.6.4(9)

\section{References:}

Abhari, K., Davidson, E., \& Xiao, B. 2017. Perceived Individual Risk of Co-innovation in Collaborative Innovation Networks.

Abrhám, J.; \& Lžičař, P. 2018. Risk management in the sustainable development: Analysis of a selected key industry. Journal of Security and Sustainability Issues, 8(2): 171-180. http://doi.org/10.9770/jssi.2018.8.2(5)

Balaz, P. 2015. Japan's economy in the 21st century Trends and challenges, Ekonomicky Casopis, 63(8): 869-872.

Balaz P.; \& Hamara A. 2016. Export dependency of Slovakia on German's economy. Politicka Ekonomie, 64(5): 573-590. http://doi.org/10.18267/j.polek.1088

Berry, A. 1997. SME competitiveness: The power of networking and subcontracting, Inter-American Development Bank.

Brakman, S. [et al.]. 2006. Nations and firms in the global economy - an introduction to international economics and business. Cambridge: Cambridge University Press, 2006.

Burda, P.; Abrham, \& J.; \& Horvathova, Z. 2017. Factors Influencing Online Civic Participation in Mid-Sized Czech Towns. Transformations in Business \& Economics, 16(2B): 607-618.

Camarinha-Matos, L. M., Bénaben, F., \& Picard, W. 2015. Risks and Resilience of Collaborative Networks. Springer.

Cihelkova, E. 2016. Formation of the theoretical framework for the comparative analysis of post-socialist countries. Agricultural Economics (Czech Republic), 62(9): 407-420. http://doi.org/10.17221/18/2016-AGRICECON

Dano, F.; \& Lesakova, D. 2018. The Role of Environmental Stimuli in Shopping Evaluation and Responses, Ekonomicky Casopis, 66(5): 465-478.

De Castro, T.; \& Hnat, P. 2017. Czech FDI Performance: Between Global Value Chains and Domestic Reforms, Foreign Direct Investment in Central and Eastern Europe: Post-Crisis Perspectives, Book Series: Studies in Economic Transition, http://doi.org/10.1007/978-3-31940496-7_3

Drulák, P.; \& Drulákova, R. 2014. The richness of the liberal tradition in international relations: Karl Deutsch on political community and the European integration. International Relations, 28(3): 333-349. http://doi.org/10.1177/0047117814545951

Fabuš, M. 2017. Current development of business environment in Slovakia and Czech Republic. Entrepreneurship and Sustainability Issues, 5(1): 127-137. https://doi.org/10.9770/jesi.2017.5.1(10)

Fabus, M. 2018. Business environment analysis based on the Global Competitiveness Index (GCI) and Doing Business (DB): case study Slovakia. Journal of Security and Sustainability Issues, 7(4): 831-839. http://doi.org/10.9770/jssi.2018.7.4(18)

Fabus, M.; \& Csabay, M. 2018. State aid and investment: case of Slovakia, Entrepreneurship and Sustainability Issues, 6(2): 480-488. http://doi.org/10.9770/jesi.2018.6.2(1)

Fabuš, Michal. 2014. Foreign direct investment and its impact on the Slovak Republic's economy. Ekonomičnij časopis - XXI. no. 9-10(1), 42-45.

Fabuš, M. 2015. Impact of foreign direct investment on unemployment development in selected regions of Slovak Republic. Economic Annals XXI. Vol. 19, no. 155(11-12): 63-66.

Falkner, E. M.; \& Hiebl, M. R. 2015. Risk management in SMEs: a systematic review of available evidence, The Journal of Risk Finance, 16(2): 122-144.

Fiala, R., Hedija, V. 2015. Gibrat's law and empirical studies. Proceedings of the 10th International Scientific Conference Financial management of Firms and Financial Institutions, 254-262.

Fojtikova, L. 2016. Trends in the revealed comparative advantages of the EU member states, Economic Annals-XXI, 161(9-10): 7-11. https://doi.org/10.21003/ea.V161-02 


\section{ENTREPRENEURSHIP AND SUSTAINABILITY ISSUES}

ISSN 2345-0282 (online) http://jssidoi.org/jesi/

2019 Volume 6 Number 4 (June)

http://doi.org/10.9770/jesi.2019.6.4(9)

Fojtikova, L.; \& Stanickova, M. 2017. The EU member states export competitiveness and productivity, Politicka Ekonomie, 65(6): 669689. http://doi.org/10.18267/j.polek.1169

Fomina, A.; \& Berduygina, O., \& Shatsky, A. 2018. Industrial cooperation and its influence on sustainable economic growth. Entrepreneurship and Sustainability Issues, 5(3): 467-479.

Hamilton, L.; \& Wepster, Ph. 2009. The International Business Environment, New York: Oxford University Press.

Hanulakova, E.; \& Dano, F. 2018. Circular economy as a new managerial approach. AD ALTA-Journal of Interdisciplinary Research, 8 (1): 95-98.

Hilkevics, S.; Semakina, V. 2019. The classification and comparison of business ratios analysis methods, Insights into Regional Development 1(1): 47-56. http://doi.org/10.9770/IRD.2019.1.1(4)

Horecký, J. 2018. Operation and action of a trade union (in terms of Czech Republic labour law), Central European Journal of Labour Law and Personnel Management, 1(1): 17-27.

Hudáková, M.; \& Masár, M. 2018. Research of Statistical Dependence of Perceived Personnel, Legal and Security Risks on the Size of SMEs in the Transport Sector, Proceedings of 22nd International Scientific Conference. Transport Means 2018. Ed. by Kersys, R. Kowno: Kaunas University of Technology, $1137-1141$

Koval'ová, M.; \& Kulčár, L. 2017. Innovation management and information acquisition, Acta Oeconomica Universitatis Selye, 6 (2): 101108

Lemańska-Majdzik, A.; \& Okręglicka, M. 2015. Identification of Business Processes in an Enterprise Management. Procedia Economics and Finance, Vol. 27. In: 22 ${ }^{\text {nd }}$ International Economic Conference "Economic Prospects in the Context of Growing Global and Regional Interdependencies, 15-16.05.2015, Sibiu, Rumunia; 394-403

Lewandowska, A.; \& Stopa, M. 2018. SMEs innovativeness and institutional support system: the local experiences in qualitative perspective. Polish case study, Oeconomia Copernicana, 9(2): 333-351

Lipkova, L.; \& Braga, D. 2016. Measuring Commercialization Success of Innovations in the EU, Marketing and Management of Innovations, 4: 15-30.

Lipkova, L.; \& Hovorkova, K. 2018. Economic situation in Norway after the outbreak of the global financial and oil crises in the context of EU integration trends, Economic Annals-XXI, 169(1-2): 12-14.

Lorincová, S. 2018. Human resource and corporate culture: Gender-based differences in the assessment, Central European Journal of Labour Law and Personnel Management, 1(1): 28 - 45.

Machkova, H.; \& Sato, A. 2017. Analysis of Competitiveness of Belgian Sugar Industry, Listy Cukrovarnicke a Reparske, 133(12): 390392.

Malec, L.; \& Abrham, J. 2016. Determinants of tourism industry in selected European countries: a smooth partial least squares approach, Economic Research-Ekonomska Istrazivanja, 29(1): 66-84. http://doi.org/10.1080/1331677X.2016.1156554

Mészáros, M. 2018. Employing” of self-employed persons, Central European Journal of Labour Law and Personnel Management, 1(1): $46-67$.

Miklosik, A.; \& Kuchta, M.; \& Zak, S. 2018. Monetising Content through Delivery of Advertisements: The Case of Ad Blockers, AD ALTA-Journal of Interdisciplinary Research, 8(1): 175-179.

Mura, L.; \& Daňová, M.; \& Vavrek, R.; \& Dúbravská, M. 2017. Economic freedom - classification of its level and impact on the economic security, AD ALTA-Journal of Interdisciplinary Research, 7(2): 154 - 157.

Mura, L.; \& Marchevska, M.; \& Dubravska, M. 2018. Slovak Retail Business Across Panel Regression Model, Marketing and Management of Innovations, 4: 203-211.

Mura, L.; \& Rózsa, Z. 2013. The impact of networking on the innovation performance of SMEs. 7th International Days of Statistics and Economics, 2013, 1036-1042. 


\section{ENTREPRENEURSHIP AND SUSTAINABILITY ISSUES}

ISSN 2345-0282 (online) http://jssidoi.org/jesi/

2019 Volume 6 Number 4 (June)

http://doi.org/10.9770/jesi.2019.6.4(9)

Newlands, D. 2003. Competition and cooperation in industrial clusters: the implications for public policy. European Planning Studies, 11(5); 521-532.

Obadi, S. M.; \& Korcek, M. 2016. The "Revealed" Comparative Advantage and Competitiveness of the EU's International Trade visa vis the USA, Ekonomicky Casopis, 64(5); 397-422.

Okanazu, O. O. 2018. Financial management decision practices for ensuring business solvency by small and medium scale enterprises, Acta Oeconomica Universitatis Selye, 7(2); 109-121.

Rosas, J.; Macedo, P.; Tenera, A.; Abreu, A.; \& Urze, P. 2015. Risk assessment in open innovation networks, Working Conference on Virtual Enterprises, Springer, Cham, 27-38.

Sejkora, J. 2014. Poor Economics: A Radical Rethinking of the Way to Fight Global Poverty, Ekonomicky Casopis, 62(4): $431-435$.

Sejkora, J.; \& Sankot, O. 2017. Comparative advantage, economic structure and growth: The case of Senegal, South African Journal of Economic and Management Sciences, 20(1), Article Number: a1685. http://doi.org/10.4102/sajems.v20i1.1685

Stasiak-Betlejewska, R. 2015. Clusters as the element of eco-innovations promoting in the European construction on the Polish example, Acta Oeconomica Universitatis Selye, 4(2): 182-197.

Taušer, J.; Arltová, M.; \& Žamberský, P. 2015. Czech exports and german GDP: A closer look, Prague Economic Papers, 24(1): 17-37.

Taušer, J.; \& Čajka, R. 2014. Hedging techniques in commodity risk management, Agricultural Economics (Czech Republic), 60(4): 174182.

Tvaronavičienè, M. 2014. If industrial sector development is sustainable: Lithuania compared to the EU. Journal of entrepreneurship and sustainability, (1), 3 .

Varadzin, F. 2016. Global Public Goods and Integration. Proceedings of the 3rd International Conference on European Integration 2016 (ICEI 2016), 2016, 1052-1059

Vojtovic, S. 2016 The Impact of the Structural Funds on Competitiveness of Small and Medium-Sized Enterprises, Journal of Competitiveness, 8(4): 30-45. http://doi.org/10.7441/joc.2016.04.02

Vojtovic, S.; Navickas, V., \& Gruzauskas, V. 2016. Sustainable Business Development Process: The Case of the Food and Beverage Industry, Advancing Research in Entrepreneurship in the Global Context, 2016, 1077-1089

Wang, L.; Luo, F. 2011. The Study of the Risk Decision of Cluster Park Engineering, Systems Engineering Procedia, 1, 221-227

Zadrazilova, D. 2016. Current Trends in German Sugar Industry, Listy Cukrovarnicke a Reparske, 132(12): 390-393.

Zak, S. 2012. International Marketing: Theory, Practices and New Trends. Prague Economic Papers, 21(2): 251-254.

Zemanova, S.; \& Drulakova, R. 2016. Making Global Goals Local Business in V4 Countries: V4 Entrepreneurs and the UN Global Compact, Globalization and its Socio-Economic Consequences, 16th International Scientific Conference Proceedings, PTS I-V, 24902497.

Žul'ová, J.; Švec, M.; \& Madleňák, A. 2018. Personality aspects of the employee and their exploration from the GDPR perspective, Central European Journal of Labour Law and Personnel Management, 1(1): 68 - 77. 


\section{ENTREPRENEURSHIP AND SUSTAINABILITY ISSUES}

ISSN 2345-0282 (online) http://jssidoi.org/jesi/

2019 Volume 6 Number 4 (June)

http://doi.org/10.9770/jesi.2019.6.4(9)

\section{Aknowledgements}

This research was supported by the project, which has received funding from the Ministry of Education of the Slovak Republic and of Slovak Academy of Sciences with title Risk management of SMEs in the context of clusters' involvement activities in the Slovak Republic, reg.Nr.VEGA [1/0918/16]

Katarina HAVIERNIKOVA, Ing., PhD., Katarína Havierniková, PhD, works as an Assistant Professor at the Faculty of Social and Economic Relations, Alexander Dubček University of Trenčín. Her research interests are: small and medium sized enterprises, clusters, risk management and regional development. She is principal investigator in the project VEGA 1/0918/16 Risk management of SMEs in the context of clusters' involvement activities in the Slovak Republic.

ORCID ID: 0000-0002-9019-8684

Marcel KORDOŠ, PhD, assistant professor at the Department of Public Administration and Regional Economy, Faculty of Social and Economic Relations at Alexander Dubcek University of Trencin, Slovakia; editor-in-chief of international scientific journal Social and Economic Revue, graduated from the University of Economics in Bratislava majoring in International Economic Relations; the author of more than 100 scientific papers and publications published domestically and abroad (Czech Republic, Germany, Lithuania, Ukraine, Poland and Russia). Completed professional internships and lecturing stays at Polytechnic University of Valencia, University of Alicante and Plekhanov Russian University of Economics in Moscow. Fields of scientific interest: international economic relations, international economics, world economy global issues, economic diplomacy, integration processes in European Union, EU economy policies, US and EU foreign trade strategies and their mutual trade relations and issues.

ORCID ID: 0000-0002-1833-7096

Researcher ID: P-4568-2018

Copyright (C) 2019 by author(s) and VsI Entrepreneurship and Sustainability Center This work is licensed under the Creative Commons Attribution International License (CC BY). http://creativecommons.org/licenses/by/4.0/

CC) (i) Open Access 